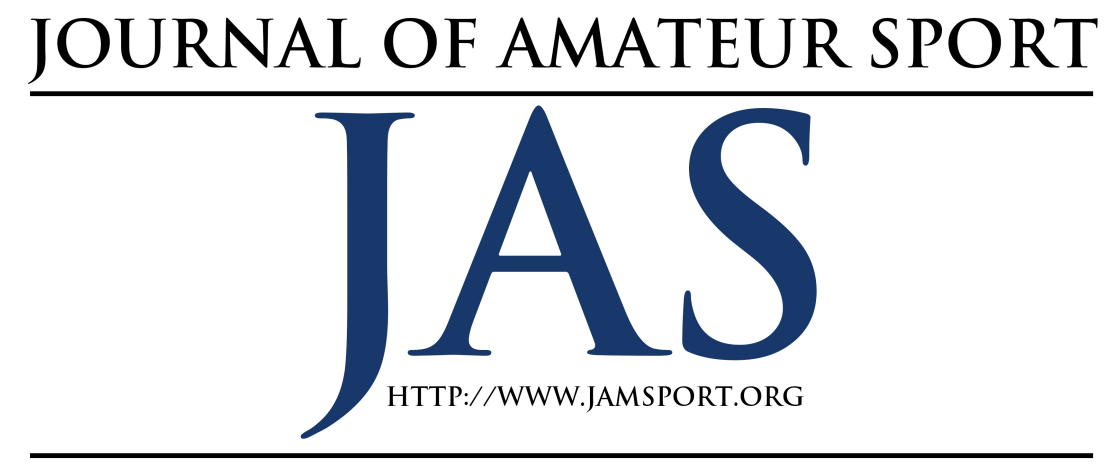

\title{
The Salience of Sport in Cross-Race Friendship Selection
}

\author{
Gareth J. Jones \\ Kyle S. Bunds \\ Troy A. Carlton \\ Michael B. Edwards \\ Jason N. Bocarro \\ North Carolina State University
}

In response to growing racial concerns, stakeholders have called for programs that facilitate positive cross-race interactions. Adolescence has been targeted as the most effective life stage to initiate programs promoting relationships. Since schools are one of the primary social influences on adolescent development, they have been emphasized as a particularly important setting for promoting intergroup contact. Sport plays an important role in the experiences of students, and contributes to intergroup relations within a school. The purpose of this study is to examine the unique effect of sport participation on cross-race friendship selection. Using data from Wave I of The National Longitudinal Study of Adolescent Health (Add Health), mixed-effects regression models and analysis of variance (ANOVA) were used to assess the effects of sport participation on friendship heterogeneity. Overall, participation in sport activities did not significantly influence the racial heterogeneity of adolescent's friendship networks.

$\mathrm{T}$ (2013) suggesting it is the "essential task" of the 21 st century (p. 1). While any singular definition of the term would fall short of capturing its multifaceted nature, a civil society can broadly be characterized as "a social infrastructure of dense networks of face-to-face relationships that cross-cut existing social cleavages such as race, ethnicity, class, sexual orientation, and gender" (Edwards, Foley, \& Diani, 2001, p. 17). Although progress has certainly been made on this front, most societies remain deeply divided along one or more of these 
social cleavages. Such schisms not only inhibit the development of civil societies, but also contribute to the prevailing social order, which perpetuates inequality through various forms of overt and latent discrimination (Bourdieu, 1986; Weber, 1957).

In the United States, racial dimensions of inequality are particularly salient due to the deep-rooted history of racism in American history, culture, and politics. Although the presidential election of Barack Obama in 2008 led many to conclude the U.S. was entering a "post-racial" era, racial inequalities have persisted and in many cases deepened throughout the country (Omi \& Winant, 2015). The social prejudices that accompany these inequalities, combined with visual categorizations of race, contribute to the largest divide in social networks in the United States (McPherson, Smith-Lovin, \& Cook, 2001). Strong racial homophily is evident in just about every social relation one encounters, from marriage (Kalmign, 1998) to work associations (Ibarra, 1995).

For example, a nationally representative sample in 1985 found that only $8 \%$ of adults "discussed important matters" with a person of another race (Marsden, 1987), and while the overall racial heterogeneity of the American population has increased markedly since this time, recent studies suggest the salience of race in social relations has remained constant (Smith, McPherson, \& Smith-Lovin, 2014). This trend has led to growing concerns that the
United States is fragmenting rather than integrating (Lichter, 2013), causing political and cultural discord that severely inhibits the progression of a civil society.

In response to these concerns, numerous politicians, policymakers, and scholars have called for programs that facilitate positive cross-race interactions. While promoting these relationships is germane at every age level, adolescence has been targeted as the most effective life stage to initiate such programs (Watkins, Larson, \& Sullivan, 2007). Adolescence is a period of considerable psychological growth, yet it is also when the formation of strong social cliques can magnify perceived inter-group differences (Brown, 2004). While they possess the mental dexterity to develop a better understanding of various out-groups, many adolescents incubate themselves in same-group relationships which enable discriminatory attitudes and behavior (Hamm, Brown, \& Heck, 2005; Killen, LeeKim, McGlothlin, \& Stangor, 2002). As a result, adolescence is considered a "significant turning point" (Watkins et al., 2007, p. 381), where individuals either develop the competencies to form crossgroup relationships, or contribute to the further fragmentation of society.

Since schools are one of the primary social influences on adolescent development (Brown \& Evans, 2002), they have been emphasized as an important setting for promoting intergroup contact (Hewstone et al., 2015). After the Supreme Court's watershed ruling on Brown v. Board of 
Education in 1954, various techniques have been employed to promote cross-group interactions in schools (Rivkin, 2000). While the results of these efforts have been largely mixed (Reardon, Grewal, Kalogrides, \& Greenberg, 2012), extracurricular activities have been highlighted as an especially viable mechanism for promoting positive intergroup contact (Crain, 1981; Eccles, Barber, \& Stone, 2003; Knifsend \& Juvonen, 2013; Scott \& Damico, 1984). For example, Moody (2001) found that interracial friendships were more likely in schools with racially diverse extracurricular programs, while Crain (1981) found that schools with high extracurricular participation had greater interracial contact and stronger bonds between students.

As the most popular extracurricular activity in terms of participation (Fredricks \& Eccles, 2006), sport plays a particularly important role in the experiences of students and contributes immensely to intergroup relations within schools (Clotfelter, 2002). Ideally, sport provides active goal-oriented settings for teammates to work together towards common objectives (e.g. winning), which helps reduce prejudice and promote acceptance among players (Miracle, 1981; Pettigrew, 1998). This process has received considerable support from school administrators and is romanticized with great effect in various forms of sport media and movies (Leary, 2013; Rowe, 2004). However, empirical studies assessing the impact of sport participation on racial integration have produced inconsistent findings, with some concerned sport may actually intensify racial segregation in schools (Chu \& Griffey, 1985; McPherson, 1976; Sargent, 1972). While sport has helped facilitate positive cross-group interactions in certain instances (Clotfelter, 2002; Harris, 1998; Skinner, Zakus, \& Cowell, 2008; Stodolska \& Alexandris, 2004; Tonts, 2005), it has also been a context for racial and cultural dissonance (Hawkins, 2013). Clearly, more work is needed to understand the factors and conditions that help facilitate this process (Cunningham, Bopp, \& Sagas, 2010; Lyras \& Welty Peachey, 2011).

This paper examines how sport participation is associated with cross-race friendship selection in schools. After controlling for key structural and social characteristics of schools that are known to influence race relations, the friendship racial heterogeneity of sport participants was compared with other extracurricular participation categories (e.g., academic, performing arts, other). Key social structural characteristics of student's extracurricular profiles were then analyzed to examine these differences and further explicate the association between sport and cross-race friendship selection. Finally, key characteristics between specific sport activities were assessed to highlight their potential influence on cross-race friendship selection. 


\section{Theoretical Background}

Allport's (1954) contact theory is the predominant framework guiding initiatives that address issues of racism, prejudice, and discrimination through intergroup contact. According to Allport (1954), cross-group contact is positive and effective only when four conditions are met: (1) equal status of the groups in the situation, (2) common goals, (3) intergroup cooperation, and (4) support from the authorities, laws, and customs. If these conditions are present, intergroup contact is hypothesized to reduce prejudice and mitigate conflicts between groups (Pettigrew, Tropp, Wagner, \& Christ, 2011). Recently, scholars have highlighted the importance of a fifth condition, friendship potential, which has been added to Allport's initial model (Pettigrew, 1998; Pettigrew \& Tropp, 2006). From this perspective, situations that provide close interactions between participants facilitate friendship-developing mechanisms (e.g. self-disclosure) that enhance positive contact effects (Pettigrew et al., 2011). By promoting what Allport (1954) described as intimate contact, it is posited that friendship inherently evokes the four conditions that promote positive intergroup relations (Pettigrew, 1998). In addition, since friendship entails prolonged interactions that extend beyond the immediate situation, the likelihood that positive effects will generalize to other social contexts and outgroups is increased (Pettigrew, 1998; Pettigrew et al., 2011;
Turner, Hewstone, Voci, Paolini, \& Christ, 2007).

Despite a strong theoretical base for contact theory, empirical studies of intergroup contact have produced mixed results, with some suggesting intergroup contact can actually intensify schisms between groups (Pettigrew et al., 2011). These studies highlight additional factors such as the characteristics of the contact setting, the individuals and groups being targeted, and the conflict(s) under study which can influence intergroup interactions (Patchen, 1999; Pettigrew et al., 2011; Stephan, 1987). In addition, since effects (positive or negative) are the product of a specific set of conditions that may not be replicable in other settings, it is difficult to generalize beyond the immediate situation (Pettigrew, 1998). Consequently, while positive intergroup relations may be produced in a particular setting, these sentiments do not automatically extend to broader social relations. This highlights a need to understand how the structural arrangement of social situations may influence the clustering of ties amongst adolescents, particularly in schools.

Blau's (1977) macrosociological theory is a common framework for this analysis, and highlights two predominant factors that influence intergroup contact (Blum, 1985; Floyd \& Shinew, 1999). First, the probability of intergroup relations is inversely related to the size of one's ingroup, such that those with smaller ingroups have greater interaction with out- 
groups, while those with larger in-groups have less interaction with out-groups (Blau, 1974, 1977). The size of the overall population is also an important consideration related to this factor, since larger populations afford more potential relations from which students can select similar ties (Blau, 1994). Second, the more heterogeneous a population is on any nominal characteristic (e.g. race), the more likely individuals are to engage in crossgroup relations based on that characteristic (Blau, 1977). This is perhaps the most straightforward of Blau's arguments, as opportunities for adolescent cross-race friendship formation depend upon racial mixing opportunities (Echols \& Graham, 2013; Graham, Munniksma, \& Juvonen, 2014; Simpkins, Schaefer, Price, \& Vest, 2013).

When these factors are applied to the school context, it is important to consider that the social dynamics of student bodies are much more malleable than general populations, since students interact within a relatively bounded setting and various institutional policies may influence interracial mixing opportunities. Among these, school sport activities have been highlighted as one of the most effective policies for promoting positive interracial contact (Eccles et al., 2003; Knifsend \& Juvonen, 2013). Well-directed athletic teams are thought to provide a safe and autonomous environment for interracial teammates to work together towards common goals and build positive relationships (Pettigrew, 1998). Due to the high social status of sport within schools, the positive out-group perceptions formed by athletes are also expected to diffuse across the broader school network faster and more efficiently than those formed in other activity types (e.g. performing arts, academic clubs) (Schaefer, Simpkins, Vest, $\&$ Price, 2011). Moreover, the prominence and popularity of Black sporting celebrities has led to a widespread belief that sport is "colorblind" (Winograd, 2011), and offers a prime opportunity for racial self-expression (Dyson, 1994; Jarvie \& Reid, 1997), with several studies indicating sport participation has improved race relations within schools (Hartmann et al., 2012; Schaefer et al., 2011).

The association between sport participation and positive intergroup contact is supported by studies examining racial (Hartmann, Sullivan, \& Nelson, 2012), cultural (Lyras \& Welty Peachey, 2011), and class-based (Skinner et al., 2008) divides. The theoretical rationale is grounded in Feld's (1981) focus theory, which suggests individuals participating in activities organized around similar foci are more likely to form interpersonal relationships. This viewpoint proposes that in addition to the direct impact of similarities across categorical attributes, shared relations to a foci (i.e., sport activity) can indirectly influence students through mutual interactions (Feld, 1981). From this perspective, since the clustering is focused around the purpose or objectives of the 
sport, rather than the socio-demographic profiles of participants, sport activities offer ideal settings for cross-race interactions that might otherwise be considered incongruous given the racial composition of the school or community (Crain, 1981; Hansen, Larson, \& Dworkin, 2003). Although categorical attributes remain salient in sport settings, Feld (1981) suggests that "unless the similarities of attitudes, attributes, and social positions are translated into the structuring of focused interaction, their selective effects on tie formation will be overwhelmed by structural features that do focus the interaction." (p. 1019).

Yet involvement in organized sport activities does not inherently facilitate positive cross-race interactions (Chu \& Griffey, 1985; Rees \& Miracle, 1984). Different sport activities offer unique structural and social contexts that can create status discrepancies among participants based on race (Floyd, 1998; Floyd \& Shinew, 1999). These discrepancies influence participation rates among different races (Floyd, Shinew, McGuire, 1994; Philipp, 1994, 2000; Shinew, Floyd, McGuire, \& Noe, 1995; Shinew, Floyd, \& Parry, 2004) and significantly impact crossrace interactions within sport settings (Floyd \& Shinew, 1999). In the United States, the status value of race is especially salient in sport (Carrington, 2013; Frey \& Eitzen, 1991; Pitts \& Yost, 2013). Minorities are overrepresented in some sports yet drastically underrepresented in others (Edwards, Bocarro, Kanters, \& Casper,
2011; Goldsmith, 2003; Phillips, 1976), and strong racial connotations remain associated with certain sport activities and specific athletic positions (e.g., stacking) (Sack, Singh, \& Thiel, 2005). In addition, factors influencing what Phillips (1976) described as the "sports opportunity structure" continue to perpetuate imbalances by limiting participation among certain demographics (p. 48). For example, the cost, time, and resources needed to play certain sports has been shown to inhibit participation among low-income and minority students (Casper, Bocarro, Kanters, \& Floyd, 2011; Edwards et al., 2011; Goldsmith, 2003; Lee, Burgeson, Fulton, \& Spain, 2006), and can lead to drastically different racial profiles among different sports.

The confluence of these factors influences the association between sport and cross-race friendship by creating settings that are not conducive to positive cross-race interactions. In addition, racial imbalances within sport settings may create status differences that reduce the likelihood of forming cross-race friendships among adolescents (Floyd \& Shinew, 1999). While previous research has focused primarily on characteristics of sports that are thought to contribute to cross-race friendship formation, such as teamwork and identity (Lawrence, 2005), there has been less work examining the broader social structural features of sport activities. This limitation is noteworthy considering the racial and social characteristics of sport settings play an important role in providing the conditions 
necessary for cross-race friendship formation. In addition, it is important to consider how the association between sport and cross-race friendship formation compares to other extracurricular activities (e.g., academics, performing arts, other), since school administrators must understand how different combinations influence cross-race relations between their students.

The purpose of this study was to examine the association between sport participation and cross-race friendship selection among middle and high school students. The analysis was guided by three primary research questions:

1. After controlling for key structural and social characteristics of the school context, do sport participants have more racially heterogeneous friendship networks than participants in other extracurricular activities (e.g., academic, performing arts, and other activities)?

2. Do Blau's (1977) structural principles influence the association between extracurricular participation and crossrace friendship, and what is the relative effect of sport?

3. How do these structural factors vary across different sport activities, and is this variance consistent across races?

\section{Methods}

\section{Data}

Our analysis utilized secondary data from The National Longitudinal Study of Adolescent Health (Add Health). Add
Health is a nationally representative sample of students from middle schools and high schools throughout the United States (grades 7-12). Schools were systematically selected with probability proportional to enrollment from a list of 80 sampling strata, which were delineated by factors such as geographic location, school size, and grade span. Surveys were administered to the complete student population within these schools to gather information on a variety of health and behavioral constructs. In addition, global friendship network data was collected by asking students to nominate up to five male and five female friends from a roster of students enrolled in either their school or a sister school. Interviews were also conducted with administrators, which provided information related to the organizational features of the school.

The data for this particular study comes from the adolescent in-school questionnaire, which was collected during Wave I in 19941995. Wave I is the only iteration of this study with global network information, and contains the largest sample of adolescents and schools. Since this study required both school level and individual level data, only schools that completed both the administrator interviews and the student survey were included. In addition, to ensure the reliability of global network measures, only schools with over $50 \%$ response rates were included. The final sample consisted of 126 schools and 49,820 students who responded to all variables of interest. 


\section{Measures}

According to the model of contact theory outlined by Pettigrew and Tropp (2006), interactions that facilitate friendship formation enhance positive contact effects. From this perspective, someone who perceives an individual from another group (e.g. race) as a friend must possess a certain level of acceptance for that group (Pettigrew, 1998). In addition, this friendship implies that positive perceptions are more likely to be generalized across other social contexts and outgroups as well (Pettigrew et al., 2011). Since this process is guided by the perception of friendship, not necessarily its reciprocation, we focused on the racial heterogeneity of a student's sendnetwork (e.g., adolescents nominated by ego). This measure represents the racial heterogeneity of the friendship network identified by ego, and ranges from 0 (all friends are the same race as ego) to 1 (all friends are a different race than ego).

The homophilizing effects of gender and SES have been noted in previous research, as adolescents are generally more likely to select friends who are similar on these characteristics (Brown \& Larson, 2009; Schaefer et al., 2011). In addition, adolescents with larger friendship networks are expected to have more opportunities to establish cross-race friendships than adolescents with smaller friendship networks (Simpkins et al., 2013). To account for the potentially spurious effects of these individual characteristics, we included measures for gender, socio- economic status (SES), and friendship network size. Gender was measured with a binary dummy coded variable ( $1=$ female, $0=$ male), and SES was measured on a 4point ordinal scale of maternal education ranging from 0 (Less than high school) to 3 (College degree or higher). The size of friendship networks was measured using Bonacich centrality, which measures a student's centrality weighted by the centrality of their nominated friends (Bonacich, 1987). Bonacich centrality was chosen because it accounts for both the size of a student's friendship network and that of their friends. Race was included as an individual level variable, and classified into four categories: 1) Black, 2) Hispanic/Latino, 3) Other/Mixed, and 4) White.

To control for the influence of key structural and social factors at the school level, we adapted several measures from Moody's (2001) study of institutional factors that influence friendship segregation. The structural measures included the number of students enrolled in the school, racial busing ( 1 = racial busing, $2=$ no racial busing), a public/private distinction ( $1=$ public, $2=$ private), and two measures of geographic region $(1=$ South, $2=$ Non-South; $1=$ urban, $2=$ suburban, $3=$ rural). The social measures included gender and grade friendship segregation, relative density, racial composition, and the racial in-group size. Following Moody (2001), Freeman's (1972) segregation index was used to as an indicator of gender and grade segregation, 
an adjusted relative density measure was used to account for the limited selection criteria (e.g., only up to 10 friendship nominations), and racial composition was measured using a generalized heterogeneity measure which can be interpreted as the likelihood that any two students chosen at random are of a different race. Racial ingroup size was measured as the proportion of the overall student body that was the same race as ego.

\section{Analysis}

Data were analyzed using Statistical Analysis System (SAS) software version 22. The first two research questions were answered using mixed-effects regression models. This technique was chosen due to the sampling design of the Wave I dataset, which was based on a stratified selection of schools. Since the variance between individual responses within schools was expected to be correlated, we incorporated these correlations into our model by expressing measures related to key structural and social features as fixed effects, and measures corresponding to individual responses as random effects. The first model assessed the association between sport and friendship heterogeneity relative to other extracurricular activities (e.g., academics, performing arts, other). To allow for meaningful comparisons between groups, seven discrete participation categories were created: 1$)$ sport activities only (Sport Only), 2) sport in combination with other activities (Sport Combo), 3) academic activities only (Academic Only), 4) performing arts activities only (Performing Arts Only), 5) other activities only (Other Only), 6) combination of other non-sport activities (Other Combo), and 7) no extracurricular activities (None). An interaction effect was also included to determine if these associations were dependent on race.

The second model assessed specific features of student's extracurricular repertoires that may influence friendship heterogeneity, and included several additional variables to represent key structural features based on Blau's (1977) principles. The size of a student's extracurricular repertoire was measured as the average size of the extracurricular activities they participated in (Size). The racial heterogeneity of a student's extracurricular repertoire was measured using the same generalized heterogeneity formula that was used for the school-level variable (Heterogeneity). Racial in-group was measured as the proportion of participants in their extracurricular repertoire that was of the same race (Racial In-group). An interaction effect between these two variables (Heterogeneity*Racial In-group) was included to assess their interdependency. Finally, the relative effect of sport was examined by including variables for the number of extracurricular activities (Number of Activities) a student participated in and the proportion of these activities that were sport (Proportion Sport).

To answer our third question, we utilized a one-way analysis of variance 
(ANOVA) model with Bonferroni post-hoc analysis to compare the racial distribution and heterogeneity of different sport activities to the overall school population. Two measures were calculated from the total sample for this analysis. First, a relative in-group ratio was calculated for each racial category by dividing the proportion ingroup within a sport activity by the proportion in-group in the entire school. A measure under 1 indicated that the racial ingroup proportion within an activity was less than the proportion in the overall school. A measure over 1 indicated that the racial ingroup proportion within an activity was greater than the proportion in the overall school. If a particular race was not represented in a school, the ratio was set as a missing value. Second, a relative racial heterogeneity ratio was calculated by dividing the racial heterogeneity of each sport activity by the racial heterogeneity of the overall school. A measure under 1 indicated the racial heterogeneity of an activity was less than the racial heterogeneity of the overall school, and a measure over 1 indicated the racial heterogeneity of an activity was greater than the overall school.

\section{Results}

Table 1 displays the individual-level results from the first mixed-effects regression model (the full model can be found in Appendix 1). Increases in Bonacich centrality were associated with significant increases in the racial heterogeneity of students' friendship selections $(B=.043, \mathrm{p}<.001)$, indicating students with larger overall friendship networks selected more racially heterogeneous friends than students with sparser friendship networks. SES was also significantly related to friendship heterogeneity, and indicated increases in SES were associated with significant decreases in cross-race friendship selection $(\mathrm{B}=-.005, \mathrm{p}<.001)$. In terms of race, Hispanic/Latino $(\mathrm{B}=.072, \mathrm{p}<.001)$, and Other/Mixed $(\mathrm{B}=.037, \mathrm{p}<.001)$ race students had significantly more racially heterogeneous friendship selections than White students. There was no significant difference in friendship heterogeneity between Black students and White students..

The main effects for extracurricular participation indicate that White students participating in sport and other activities $(\mathrm{B}=-.018, \mathrm{p}<.001)$, other activities only $(B=-.019, p<.05)$, and a combination of other activities $(\mathrm{B}=-.012, \mathrm{p}<.05)$ selected significantly less racially heterogeneous friends than White students participating in no extracurricular activities. The interaction between extracurricular participation and race indicated Black $(\mathrm{B}=.038, \mathrm{p}<.001)$, Hispanic/Latino $(\mathrm{B}=.027, \mathrm{p}<.01)$, and Other/Mixed race $(B=.019, \mathrm{p}<.01)$ students participating in sport and other activities had significantly more racially heterogeneous friendship selections than same race students participating in no extracurricular activities. There were no other significant associations related to 
other participation categories ( $\mathrm{p}>.05)$. These findings indicate that there is an association between participating in sport and other activities and friendship heterogeneity, but that the association is influenced by the race of the student. Specifically, there is a negative association for White students, and a positive association for Black, Hispanic/Latino, and Other/mixed race students.

This may be attributable to key structural characteristics of extracurricular activities. According to Blau's (1977) principles, the number of participants, size of one's racial in-group, and racial heterogeneity of an activity influence opportunities for cross-race contact. Since students often participate in multiple activities that structure their social relations, the second model assessed these characteristics across the breadth of student's extracurricular repertoires. The individual-level results are displayed in Table 2 (the full model can be found in Appendix 2).

Once again, increases in Bonacich centrality were associated with significant increases in the racial heterogeneity of student's friendship selections $(\mathrm{B}=.044, \mathrm{p}<$ $.001)$, and increases in SES were associated with significant decreases in the racial heterogeneity of friendship selections $(B=$ $.005, \mathrm{p}<.001)$. Hispanic/Latino $(\mathrm{B}=.069$, $\mathrm{p}<.001)$ and Mixed/Other $(\mathrm{B}=.046, \mathrm{p}<$ .001) race students had significantly more racially heterogeneous friendship selections than White students, and there were no significant differences between White and Black students ( $p>$.05). Increases in the overall size of a student's extracurricular repertoire were associated with significant decreases in racially heterogeneous friendship selections $(\mathrm{B}=-.030, \mathrm{p}<.01)$. The interaction between racial heterogeneity and racial out-group was significant $(B=$ $.116, \mathrm{p}<.001)$, indicating that the influence of racial heterogeneity was dependent on the size of a student's racial in-group. Specifically, the racial heterogeneity of a student's extracurricular repertoire was positively associated with friendship heterogeneity, but this influence was contingent on the size of their racial ingroup. Finally, the effect of the number of extracurricular activities a student participated in and the proportion of these activities that were sport was not significant (p> .05).

Table 3 displays the results of the oneway analysis of variance (ANOVA) model comparing relative racial in-group ratios between different sport types. For Black students, there were significant differences in racial in-group ratios between sport types $\left(\mathrm{F}=4.788, \mathrm{p}<.001, \mathrm{n}^{2}=.036\right)$. On average, the relative proportion of Black students participating in basketball was significantly higher than the relative proportion of Black students participating in field hockey $(\mathrm{p}<$ $.05)$, ice hockey, $(\mathrm{p}<.01)$, soccer $(\mathrm{p}<.01)$, and swimming $(\mathrm{p}<.05)$. Similarly, the relative proportion of Black students participating in track was significantly larger than the relative proportion of Black students participating in field hockey $(\mathrm{p}<$ 
$.05)$, ice hockey $(\mathrm{p}<.01)$, soccer $(\mathrm{p}<.01)$, and swimming $(\mathrm{p}<.05)$. The relative proportion of Black students participating in football was significantly larger than the relative proportion of Black students participating in ice hockey $(<.05)$. There were also significant differences in racial ingroup ratios between sport types for White students $\left(\mathrm{F}=2.645, \mathrm{p}<.01, \mathrm{n}^{2}=.018\right)$. The relative proportion of White students participating in ice hockey was significantly larger than the relative proportion of White students participating in dance $(\mathrm{p}<.05)$, basketball $(\mathrm{p}<.01)$, field hockey $(\mathrm{p}<.05)$, football $(\mathrm{p}<.01)$, swimming $(\mathrm{p}<.05)$, track $(\mathrm{p}<.01)$, volleyball $(\mathrm{p}<.01)$, and wrestling $(\mathrm{p}<.01)$. There were no significant differences between sport types for Hispanic/Latino students ( $\mathrm{p}>.05)$, and although the variance in racial in-group ratios between sport types was significant for Other/Mixed race students $(\mathrm{F}=1.899$, $\left.\mathrm{p}<.05, \mathrm{n}^{2}=.013\right)$, pairwise comparisons revealed no significant difference between specific sport types $(p>.05)$.

There were also significant differences in the relative racial heterogeneity of different sports $\left(\mathrm{F}=5.802, \mathrm{p}<.001, \mathrm{n}^{2}=\right.$ .038). The relative racial heterogeneity of field hockey was significantly lower than dance $(\mathrm{p}<.01)$, baseball $(\mathrm{p}<.01)$, basketball $(\mathrm{p}<.001)$, football $(\mathrm{p}<.001)$, soccer $(\mathrm{p}<$ $.05)$, swimming $(\mathrm{p}<.01)$, track $(\mathrm{p}<.01)$, volleyball $(\mathrm{p}<.01)$, wrestling $(\mathrm{p}<.01)$, and other sports $(\mathrm{p}<.01)$. Similarly, the relative racial heterogeneity of ice hockey was significantly lower than basketball $(\mathrm{p}<.01)$, football $(\mathrm{p}<.01)$, and track $(\mathrm{p}<.01)$. The relative racial heterogeneity of tennis was also significantly lower than basketball $(\mathrm{p}<$ $.05)$, football $(\mathrm{p}<.05)$, and track $(\mathrm{p}<.05)$.

\section{Discussion and Conclusion}

Sport activities have become one of the most popular extracurricular options available to school administrators to enhance cross-race contact opportunities for students, and are commonly believed to promote positive cross-race interactions within schools (Chu \& Griffey, 1985, Clotfelter, 2002). The widespread belief in this narrative, among other generalized assumptions, has led many administrators to invest significantly in school sport facilities, often at the expense of other academic, arts, and vocational clubs (Ripley, 2013). Yet our results suggest administrators should carefully consider these decisions. The first multi-level regression model indicated that the influence of sport participation was dependent on race, with negative influences for White students and positive influences for Black, Hispanic/Latino, and Other/Mixed students. However, after controlling for key structural characteristics of student's extracurricular repertoire, there was no significant association between sport participation and friendship heterogeneity. This indicates the structuring of extracurricular activities (i.e., size, racial ingroup, racial heterogeneity) may be more salient than sport/non-sport distinctions. Rather than prioritizing sport over other activities, school administrators should consider providing extracurricular policies that encourage positive racial mixing opportunities, regardless of the activity type.

Blau's (1977) macrosociological theory provides a useful framework to inform these decisions. While Blau's principles 
suggest cross-race contact is influenced by key features of the school setting, our results indicate these principles are applicable to extracurricular activities as well. Students who were exposed to larger segments of the school population through extracurricular participation had less heterogeneous friendships than students exposed to smaller segments. In addition, students exposed to a larger proportion of same race students in their extracurricular repertoire had less heterogeneous friendships than students exposed to a smaller proportion of same race students. Finally, increases in extracurricular racial heterogeneity were significantly associated with increases in friendship heterogeneity, yet this association was contingent on the size of one's racial in-group. These results indicate that in addition to providing settings that are appropriate for cross-race contact (Allport, 1954), sport administrators should also consider the structural characteristics of their activities. In order to facilitate positive cross-race contact, sport activities must be intentionally designed and managed to do so (Lyras \& Welty Peachey, 2011). This not only involves intentional programming to promote positive interactions within the activity, but also intentional management and administration to create settings that are most conducive to those interactions.

This may be especially important in the sport context, as previous research has revealed ongoing racial imbalances between different sport activities (Edwards et al., 2011; Goldsmith, 2003; Phillips, 1976). These imbalances were evident in our study as well, even after controlling for racial distributions at the school level. In addition to highlighting important concerns regarding sport opportunity structures and socioeconomic disadvantages, racial imbalances may influence the nature of cross-race interactions within certain sport contexts (Shinew et al., 2004). In particular, sport and leisure scholars delineate between leisure practices that facilitate true racial integration and those that simply absorb minorities in mainstream culture (Floyd, 1998; Hylton, 2010). This literature has uncovered the potential negative impact of "color-blind" policies on race relations, and specifically highlights the ramifications of institutionalized white privilege (Glover, 2007). This is an especially important consideration for school administrators with less racially heterogeneous student populations, as they must not only consider the interactions between races, but also the status discrepancies involved in these interactions (Floyd et al., 1994; Shinew et al., 2004).

These findings should be considered in light of several limitations. First, our analysis focused on only Wave I of the Add Health dataset, and is cross-sectional in nature. While several intriguing trends were identified, causality between sport participation and cross-race friendship formation cannot be implied from these results. Second, aside from distinctions between sport participation categories, there were no variables available to assess additional features of the sport environment, such as competition level or participation intensity and breadth. These are critical features of sport settings that can significantly influence the experiences of students and the likelihood for cross-race friendship formation, but are not controlled 
for in this study. Third, students typically participate in a number of different sport and other extracurricular activities, making it difficult to isolate the effects of one particular activity. Although we captured unique characteristics of each particular activity, the relative influence of these activities on participants is not known. Finally, the Wave I dataset is from 19941995, so the different school- and individual-level variables may not be representative of the current population. However, since the focus of this analysis was the on the effect of these variables on friendship heterogeneity, not estimating their distribution across the population, these findings are applicable to present-day administrators.

Recent public protests and riots in Baltimore, Ferguson, and New York underscore mounting racial tensions in the United States. Despite notions of a postracial America, it is clear that race continues to segregate social networks. As one of the most influential settings in adolescent development, schools offer a unique opportunity to shape the racial perspectives of future generations. Understanding how different mechanisms structure social relations in these settings is critical to promoting positive cross-racial contact and friendships amongst this demographic. Sport is the most popular extracurricular activity among students, and has become a popular tactic for administrators to promote racial integration in schools. However, the effectiveness of sport is not inherent. Although sport activities may promote cross-racial friendships in certain instances, these effects must be understood within the context of important social and structural features that characterize the setting. As such, administrators, coaches, and other sport personnel should monitor the racial and social patterns of their sport activities, and consider alternative activities to diversify participation. Understanding sport in relation to the broader school environment is critical to understanding how sport activities can be intentionally managed to facilitate positive cross-race relations among students. Future research should be directed to not just understanding what effects sport can influence, but also the context, conditions, and processes that contributed to this process.

\section{Acknowledgement}

This research uses data from Add Health, a program project directed by Kathleen Mullan Harris and designed by J. Richard Udry, Peter S. Bearman, and Kathleen Mullan Harris at the University of North Carolina at Chapel Hill, and funded by grant P01-HD31921 from the Eunice Kennedy Shriver National Institute of Child Health and Human Development, with cooperative funding from 23 other federal agencies and foundations. Special acknowledgment is due Ronald R. Rindfuss and Barbara Entwisle for assistance in the original design. No direct support was received from grant P01HD31921 for this analysis.

\section{References}

Allport, G. W. (1954). The nature of prejudice. Reading, MA: Addison-Wesley.

Bergerson, A. A. (2003). Critical race theory and white racism: Is there room for 
white scholars in fighting racism in education? International Journal of Qualitative Studies in Education, 16(1), 51-63.

Blau, P. M. (1974). Parameters of social structure. American Sociological Review, 39, 615-635.

Blau, P. M. (1977). A macrosociological theory of social structure. American Journal of Sociology, 83(1), 26-54.

Blau, P. M. (1994). Structural contexts of opportunities. Chicago, IL: University of Chicago Press.

Blum, T. C. (1985). Structural constraints on interpersonal relations: A test of Blau's macrosociological theory. American Journal of Sociology, 91, 511521.

Bonacich, P. (1987). Power and centrality: A family of measures. American Journal of Sociology, 92, 1170-1182.

Bourdieu, P. (1986). The forms of capital. In J. G. Richardson (Ed.), Handbook of theory and research for the sociology of education (pp. 241-253). New York, NY: Greenwood Press.

Brown, B. B. (2004). Adolescents' relationships with peers. In R. M. Lerner \& L. Steinberg (Eds.), Handbook of adolescent psychology (2nd ed., pp. 363-394). Hoboken, NJ: Wiley.

Brown, R. \& Evans, W. P. (2002). Extracurricular activity and ethnicity: Creating greater school connection among diverse student populations. Urban Education, 37, 41-58.
Brown, B. B., \& Larson, J. (2009). Peer relationships in adolescence. In R. M. Lerner \& L. Steinberg (Eds.), Handbook of adolescent psychology: Contextual influences on adolescent development (3rd ed.) (p. 74-103). Hoboken, NJ: Wiley.

Carrington, B. (2013). The critical sociology of race and sport: The first fifty years. Annual Review of Sociology, 39, 379-398.

Casper, J., Bocarro, J., Kanters, M., \& Floyd, M. (2011). "Just let me play!" - Understanding constraints that limit adolescent sport participation. Journal of Physical Activity and Health, 8(Suppl 1), 32-39.

Chu, D. \& Griffey, D. (1985). The contact theory of racial integration: The case of sport. Sociology of Sport Journal, 2, 323-333.

Clotfelter, C. T. (2002). Interracial contact in high school extracurricular activities. The Urban Review, 34(1), 2546.

Crain, R. L. (1981). Making desegregation work: Extracurricular activities. The Urban Review, 13(2), 121-127.

Cunningham, G. B., Bopp, T., \& Sagas, M. (2010). Overcoming cultural barriers in sport management study abroad programs: The influence of extended intergroup contact. International Journal of Sport Management, 11(3), 347-359.

Dyson, M. (1994). Be like Mike? Michael Jordan and the pedagogy of desire, In H. Giroux \& P. McLaren (Eds.), Between Borders: Pedagogy and the Politics 
of Cultural Studies (p. 119-127).

Routledge: New York.

Eccles, J. S., Barber, B. L., Stone, M., \& Hunt, J. (2003). Extracurricular activities and adolescent development. Journal of Social Issues, 59(4), 865-889.

Echols, L. \& Graham, S. (2013). Birds of a different feather: How do crossethnic friends flock together? MerrillPalmer Quarterly, 59(4), 461-488.

Edwards, M. B., Bocarro, J. N., Kanters, M. A., \& Casper, J. (2011). Participation in interscholastic and intramural sport programs in middle schools: An exploratory investigation of race and gender. Recreational Sport Journal, 35(2). 157-173.

Edwards, B., Foley, M. W., \& Diani, M. (2001). Beyond Tocqueville: Civil society and the social capital debate in comparative perspective. Hanover, NH: University Press of New England.

Edwards, M., \& Gaventa, J. (2013). Global citizen action. New York, NY: Routledge.

Feld, S. L. (1981). The focused organization of social ties. American Journal of Sociology, 86, 1015-1035.

Floyd, M. F. (1998). Getting beyond marginality and ethnicity: The challenge for race and ethnic studies in leisure research. Journal of Leisure Research, 30(1), 3-22.

Floyd, M. F., \& Shinew, K. J. (1999). Convergence and divergence in leisure style among Whites and
African Americans: Toward an interracial contact hypothesis. Journal of Leisure Research, 31(4), 359-384.

Floyd, M. F., Shinew, K. J., \& McGuire, F. A. (1994). Race, class, and leisure activity preferences: Marginality and ethnicity revisited. Journal of Leisure Research, 26(2), 158-173.

Fredricks, J. A., \& Eccles, J. S. (2006). Is extracurricular participation associated with beneficial outcomes? Concurrent and longitudinal relations. Developmental Psychology, 42(4), 698-713.

Frey, J. H., \& Eitzen, D. S. (1991). Sport and society. Annual Review of Sociology, 17, 503-522.

Glover, T. (2007). Ugly on the diamonds: An examination of white privilege in youth baseball. Leisure Sciences, 29(2), 195-208.

Goldsmith, P. A. (2003). Race relationships and racial patterns in school sports participations. Sociology of Sport Journal, 20(2), 147-171.

Graham, S., Munniksma, A., \& Juvonen, J. (2014). Psychosocial benefits of cross-ethnic friendships in urban middle schools. Child Development, 85(2), 469-483.

Hamm, J. V., Brown, B. B., \& Heck, D. J. (2005). Bridging the ethnic divide: Student and school characteristics in African American, Asian-descent, Latino, and White adolescents' crossethnic friend nominations. Journal of Research on Adolescence, 15, 21-46. 
Hansen, D. M., Larson, R. W., \& Dworkin, J. B. (2003). What adolescents learn in organized youth activities: A survey of self-reported developmental experiences. Journal of Research on Adolescence, 13, 25-55.

Harris, J. C. (1998). Civil Society, Physical Activity, and the Involvement of Sport Sociologists in the Preparation of Physical Activity Professionals. Sociology of Sport Journal, 15(2), 138153.

Hartmann, D., Sullivan, J., \& Nelson, T. (2012). The attitudes and opinion of high school sports participants: An exploratory empirical examination. Sport, Education and Society, 17(1), 113132.

Hawkins, B. (2013). The new plantation, Black athletes, college sports, and predominantly white NCAA institutions. New York: Palgrave Macmillan.

Hewstone, M., Floe, C., Al Ramiah, A., Schmid, K., Son, E., Wolfer, R., \& Lolliot, S. (2015). Diversity and intergroup contact in schools. In R. Koopmans, B. Lancee, \& M. Schaeffer (Eds.), Social cohesion and immigration in Europe and North America: Mechanisms, conditions, and causality (208-228). New York: Routledge.

Hylton, K. (2010). How a turn to critical race theory can contribute to our understanding of 'race', racism and anti-racism in sport. International
Review for the Sociology of Sport, 45(3), 335-354.

Ibarra, H. (1995). Race, opportunity and diversity of social circles in managerial networks. Academy of Management Review, 38, 673-703.

Jarvie, G., \& Reid, I. (1997). Race relations, sociology of sport and new politics of race and racism. Leisure Studies, 16(4), 211-219.

Kalmign, M. (1998). Intermarriage and homogamy: causes, patterns and trends. Annual Review of Sociology, 24, 395-421.

Killen, M., Lee-Kim, J., McGlothlin, H., \& Stangor, C. (2002). How children and adolescents evaluate gender and racial exclusion. Monographs of the Society for Research in Child Development, 67, 120129.

Knifsend, C. A., \& Juvonen, J. (2013). The role of social identity complexity in inter-group attitudes among young adolescents. Social Development, 22(3), 623-640.

Lawrence, S. M. (2005). African American athletes' experiences of race in sport. International Review for the Sociology of Sport, 40(1), 99-110.

Leary, R. (2013). Remember the titans: A theoretical analysis. Journal of Arts \& Humanities, 2(4), 11-21.

Lee, S. M., Burgeson, C. R., Fulton, J. E., \& Spain, C. G. (2007). Physical education and physical activity: Results from the school health 
policies and programs study 2006.

Journal of School Health, 77, 435-463.

Lichter, D. T. (2013). Integration or fragmentation? Racial diversity and the American future. Demography, 50(3), 359-391.

Lyras, A., \& Welty Peachey, J. (2011). Integrating sport-for-development theory and praxis. Sport Management Review, 14, 311-326.

Marsden, P. V. (1987). Core discussion networks of Americans. American Sociology Review, 52, 122-313.

McPherson, B. (1976). The black athlete: An overview and analysis. In D. H. Landers (Ed.), Social problems in athletics: Essays in the Sociology of Sport (pp. 122-150). Champaign, Il: University of Illinois Press.

McPherson, M., Smith-Lovin, L., \& Cook, J. M. (2001). Birds of a feather: Homophily in social networks. Annual Review of Sociology, 27, 415-444.

Miracle, A. W. (1981). Factors affecting interracial cooperation: A case study of a high school football team. Human Organization, 40(2), 150-154.

Moody, J. (2001). Race, school integration, and friendship segregation in America. American Journal of Sociology, 107(3), 679-716.

Omi, M., \& Winant, H. (2015). Racial formation in the United States. New York: Routledge.

Patchen, M. (1999). Diversity and unity: Relations between racial and ethnic groups. Chicago, IL: Nelson-Hall.
Pettigrew, T. F. (1998). Intergroup contact theory. Annual Review of Psychology, 49, 65-85.

Pettigrew, T. F., \& Tropp, L. R. (2006). A meta-analytic test of intergroup contact theory. Journal of Personality and Social Psychology, 90, 751-783.

Pettigrew, T. F., Tropp, L. R., Wagner, U., \& Christ, O. (2011). Recent advances in intergroup contact theory. International Journal of Intercultural Relations, 35, 271-280.

Philipp, S. F. (1994). Racial differences in perceived leisure constraints. Perceptual and Motor Skills, 79, 13391343.

Philipp, S. F. (2000). Race and the pursuit of happiness. Journal of Leisure Research, 32(1), 121-124.

Phillips, J. C. (1976). Toward an explanation of racial variation in top-level sports participation. International Review for the Sociology of Sport, 11(3), 39-55.

Pitts, J. D., \& Yost, D. M. (2013). Racial position segregation in intercollegiate football: Do players become more racially segregated as they transition from high school to college? The Review of Black Political Economy, 40(2), 207-230.

Reardon, S. F., Grewal, E. T., Kalogrides, D., \& Greenberg, E. (2012). Brown fades: The end of court-ordered school desegregation and the resegregation of American public schools Journal of Policy Analysis and Management, 31(4), 876-904. 
Rees, C. R., \& Miracle, A. W. (1984).

Conflict resolution in games and sports. International Review for the Sociology of Sport, 19(2), 145-156.

Ripley, A. (2013, October). The case against high-school sports. The Atlantic. Retrieved January $8^{\text {th }}, 2016$ from http://www.theatlantic.com/magazin e/archive/2013/10/the-case-againsthigh-school-sports/309447/.

Rivkin, S. G. (2000). School desegregation, academic attainment, and earnings. The Journal of Human Resources, 35(2), 333-346.

Rowe, D. (2004). Sport, culture, and media: The unruly trinity. Buckingham: Open University Press.

Sack, A. L., Singh, P., \& Thiel, R. (2005). Occupational segregation on the playing field: The case of major league baseball. Journal of Sport Management, 19, 300-318.

Sargent, A. J. (1972). Participation of West Indian boys in English school sport teams. Education Research, 14, 225-230.

Schaefer, D. R., Simpkins, S. D., Vest, A. E., \& Price, C. D. (2011). The contribution of extracurricular activities to adolescent friendships: New insights through social network analysis. Developmental Psychology, 47(4), 1141-1152.

Scott, E. S., \& Damico, S. B. (1984). Extracurricular activities and interracial contact. Equity \& Excellence in Education, 21(1-6), 140-142.
Shinew, K. J., Floyd, M. F., McGuire, F. A., \& Noe, F. P. (1995). Gender, race, and subjective social class and their association with leisure preferences. Leisure Sciences, 17(2), 75-89.

Shinew, K. J., Floyd, M. F., \& Parry, D. (2004). Understanding the relationship between race and leisure activities and constraints: Exploring an alternative framework. Leisure Sciences, 26(2), 181-199.

Simpkins, S. D., Schaefer, D. R., Price, C. D., \& Vest, A. E. (2013). Adolescent friendships, BMI, and physical activity: Untangling selection and influence through longitudinal social network analysis. Journal of Research on Adolescence, 23(3), 537-549.

Skinner, J., Zakus, D. H., \& Cowell, J. (2008). Development through Sport: Building Social Capital in Disadvantaged Communities. Sport Management Review, 11, 253-275.

Smith, J. A., McPherson, M., \& SmithLovin, L. (2014). Social distance in the United States: Sex, race, religion, age and education homophily among confidants, 1985 to 2004. American Sociological Review, 79(3), 432-456.

Stephan, W. G. (1987). The contact hypothesis in intergroup relations. In C. Hendrick (Ed.),

Review of personality and social psychology. Group processes and intergroup relations (pp. 1340). Newbury Park, CA: Sage.

Stodolska, M., \& Alexandris, K. (2004). The Role of Recreational Sport in the 
Adaptation of First Generation

Immigrants in the United States.

Journal of Leisure Research, 36(3), 379-

413.

Tonts, M. (2005). Competitive sport and

social capital in rural Australia. Journal

of Rural Studies, 21(2), 137-149.

Turner, R. N., Hewstone, M., Voci, A., Paolini, S., \& Christ, O. (2007).

Reducing prejudice via direct and extended cross-group friendship. In W. Strobe, \& M. Hewstone (Eds.), European review of social psychology (pp. 212-255). Hove, U.K.: Psychology Press.

Watkins, N. D., Larson, R. W., \& Sullivan, P. J. (2007). Bridging intergroup difference in a community youth program. American Behavioral Scientist, 51(3), 380-402.

Weber, M. (1957). The theory of social and economic organization. Glencoe, Il: Free Press.

Winograd, K. (2011). Sport biographies of African American football players: The racism of colorblindness in children's literature. Race, Ethnicity, and Education, 14(3), 331-349. 


\section{Tables}

Table 1

Mixed-Effects Regression Model 1

\begin{tabular}{|c|c|c|}
\hline Effect & $B(S E)$ & $t$ \\
\hline Intercept & $.137(.05)$ & $3.01 * *$ \\
\hline \multicolumn{3}{|l|}{ Individual } \\
\hline Bonacich Centrality & $.043(<.01)$ & $10.12^{* * *}$ \\
\hline SES & $-.005(<.01)$ & $-4.90 * * *$ \\
\hline Female & $-.003(<.01)$ & -1.12 \\
\hline Black & $-.020(.01)$ & -1.81 \\
\hline Hispanic/Latino & $.072(.01)$ & $6.63^{* * *}$ \\
\hline Other/Mixed & $.037(.01)$ & $3.25^{* *}$ \\
\hline \multicolumn{3}{|l|}{ Extracurricular Participation } \\
\hline Sport Only & $.001(<.01)$ & .30 \\
\hline Sport Combo & $-.018(<.01)$ & $-3.91 * * *$ \\
\hline Academic Only & $-.011(.01)$ & -1.62 \\
\hline Performing Arts Only & $.009(.01)$ & 1.42 \\
\hline Other Only & $-.019(.01)$ & $-2.72 * *$ \\
\hline Other Combo & $-.012(.01)$ & $-2.09 *$ \\
\hline \multicolumn{3}{|l|}{ Race*Extracurricular Participation } \\
\hline Black*Sport Only & $-.001(.01)$ & -.12 \\
\hline Black*Sport Combo & $.038(.01)$ & $4.21 * * *$ \\
\hline Black*Academics Only & $.007(.01)$ & .53 \\
\hline Black*Performing Arts Only & $.013(.01)$ & .96 \\
\hline Black*Other Only & $.021(.01)$ & 1.43 \\
\hline Black*Other Combo & $.023(.01)$ & 1.90 \\
\hline Hispanic/Latino*Sport Only & $.002(.01)$ & .22 \\
\hline Hispanic/Latino $*$ Sport Combo & $.027(.01)$ & $2.96^{* *}$ \\
\hline Hispanic/Latino *Academics Only & $.003(.01)$ & .25 \\
\hline Hispanic/Latino *Performing Arts Only & $.008(.01)$ & .58 \\
\hline Hispanic/Latino *Other Only & $.028(.02)$ & 1.89 \\
\hline Hispanic/Latino $*$ Other Combo & $.011(.01)$ & .86 \\
\hline Other/Mixed*Sport Only & $.006(.01)$ & .56 \\
\hline Other/Mixed $*$ Sport Combo & $.019(.01)$ & $2.09 *$ \\
\hline Other/Mixed $*$ Academics Only & $-.010(.01)$ & -.73 \\
\hline Other/Mixed *Performing Arts Only & $.007(.01)$ & .51 \\
\hline Other/Mixed *Other Only & $.006(.02)$ & .40 \\
\hline Other/Mixed $*$ Other Combo & $.000(.01)$ & .03 \\
\hline $\mathrm{AIC}$ & -25289.0 & \\
\hline $\mathrm{BIC}$ & -25144.3 & \\
\hline Pseudo $\mathrm{R}^{2}$ & .219 & \\
\hline \multicolumn{3}{|c|}{$\begin{array}{l}\text { Note 1: * denotes } p<.05 \text {, ** denotes } p<.01 \text {, *** denotes } p<.001 \\
\text { Note 2: AIC of unconditional model }=-17334.2\end{array}$} \\
\hline
\end{tabular}

Journal of Amateur Sport Special Issue: Political Economy Jones et al., 2016 
Table 2

\section{Mixed-Regression Model 2}

\begin{tabular}{|c|c|c|}
\hline Effect & $B(S E)$ & $t$ \\
\hline Intercept & $.093(.05)$ & $1.99 *$ \\
\hline \multicolumn{3}{|l|}{ Individual } \\
\hline Bonacich Centrality & $.043(<.01)$ & $10.33 * * *$ \\
\hline SES & $-.005(<.01)$ & $-4.86 * * *$ \\
\hline Female & $-.003(<.01)$ & -1.09 \\
\hline Black & $-.010(.01)$ & -1.31 \\
\hline Hispanic/Latino & $.069(.01)$ & $8.29 * * *$ \\
\hline Other/Mixed & $.046(.01)$ & $5.56^{* * *}$ \\
\hline \multicolumn{3}{|l|}{ Extracurricular Participation } \\
\hline Number of Activities & $-.001(<.01)$ & $-2.21 *$ \\
\hline Proportion Sport & $.002(<.01)$ & .61 \\
\hline Size & $.000(<.01)$ & $-2.80 * *$ \\
\hline Heterogeneity & $.122(.01)$ & $10.70 * * *$ \\
\hline Racial In-group & $-.038(.01)$ & $-4.20 * * *$ \\
\hline Heterogeneity*Racial In-Group & $-.128(.03)$ & $-4.22 * * *$ \\
\hline AIC & -25464.3 & \\
\hline $\mathrm{BIC}$ & -25362.2 & \\
\hline Pseudo $R^{2}$ & .220 & \\
\hline $\begin{array}{l}\text { Note 1: }{ }^{*} \text { denotes } p<.05 \text {, ** denotes } \\
\text { Note 2: AIC of unconditional model }\end{array}$ & $\begin{array}{l}1, * * * \text { denote } \\
34.2\end{array}$ & \\
\hline
\end{tabular}

Journal of Amateur Sport Special Issue: Political Economy Jones et al., 2016 
Table 3

Analysis of V ariance (ANOV A) of In-Group Proportions by Sport Type

\begin{tabular}{|c|c|c|c|c|c|}
\hline Sport & Black & Hispanic/Latino & Other/Mixed & White & Race Het \\
\hline Dance & $1.13(.15)$ & $.67(.12)$ & $1.65(.19)$ & $.95(.04)$ & $.92(.04)$ \\
\hline Baseball & $.78(.07)$ & $.61(.04)$ & $1.60(.20)$ & $1.06(.03)$ & $.94(.03)$ \\
\hline Basketball & $1.74(.10)$ & $.71(.04)$ & $1.72(.25)$ & $.82(.02)$ & $1.06(.03)$ \\
\hline Field Hockey & $.49(.12)$ & $1.27(.41)$ & $3.05(.50)$ & $.91(.09)$ & $.64(.06)$ \\
\hline Football & $1.51(.12)$ & $.84(.08)$ & $1.74(.21)$ & $.87(.02)$ & $1.06(.05)$ \\
\hline Ice Hockey & $.34(.10)$ & $.95(.08)$ & $2.95(.67)$ & $1.53(.38)$ & $.76(.06)$ \\
\hline Soccer & $.42(.06)$ & $.67(.22)$ & $2.43(.34)$ & $1.13(.06)$ & $.88(.04)$ \\
\hline Swimming & $.60(.07)$ & $.82(.07)$ & $2.15(.31)$ & $.98(.04)$ & $.95(.05)$ \\
\hline Tennis & $.73(.16)$ & $.53(.14)$ & $2.29(.31)$ & $1.10(.12)$ & $.82(.06)$ \\
\hline Track & $1.79(.22)$ & $.63(.09)$ & $2.06(.38)$ & $.90(.08)$ & $1.05(.04)$ \\
\hline Volleyball & $.95(.09)$ & $.89(.05)$ & $1.89(.27)$ & $.92(.03)$ & $.95(.05)$ \\
\hline Wrestling & $1.51(.71)$ & $.86(.14)$ & $2.08(.23)$ & $.88(.04)$ & $.90(.05)$ \\
\hline Other Sport & $.73(.13)$ & $.62(.16)$ & $1.86(.19)$ & $1.06(.04)$ & $.90(.04)$ \\
\hline Total & $.99(.07)$ & $.77(.04)$ & $2.08(.09)$ & $1.01(.03)$ & $.91(.01)$ \\
\hline $\mathrm{F}$ & 4.788 & 1.718 & 1.899 & 2.645 & 5.802 \\
\hline Sig. & $<.001$ & .057 & .03 & .002 & $<.001$ \\
\hline $\mathrm{n}^{2}$ & .036 & - & .013 & .018 & .038 \\
\hline
\end{tabular}

Journal of Amateur Sport Special Issue: Political Economy

Jones et al., 2016 


\section{Appendices}

\section{Appendix 1}

Full Mixed-Effects Regression Model 1

\begin{tabular}{|c|c|c|}
\hline Effect & $B(S E)$ & $t$ \\
\hline Intercept & $.137(.05)$ & $3.01 * *$ \\
\hline \multicolumn{3}{|l|}{ School } \\
\hline Busing & $-.036(.02)$ & -1.89 \\
\hline Urban & $.029(.01)$ & $1.99 *$ \\
\hline Suburban & $.023(.01)$ & 1.83 \\
\hline South & $-.017(.01)$ & -1.82 \\
\hline Public & $-.016(.02)$ & -1.01 \\
\hline School Size & $<.001(<.01)$ & $2.71 * *$ \\
\hline Relative Density & $.171(.05)$ & $3.19 * *$ \\
\hline Gender Segregation Index & $.119(.08)$ & 1.42 \\
\hline Grade Segregation Index & $.115(.04)$ & $2.75^{* *}$ \\
\hline Racial Heterogeneity & $.101(.03)$ & $3.53^{* * *}$ \\
\hline Teacher Heterogeneity & $-.025(.03)$ & -.95 \\
\hline Proportion In-group & $-.269(.01)$ & $-21.32^{* * *}$ \\
\hline \multicolumn{3}{|l|}{ Individual } \\
\hline Bonacich Centrality & $.043(<.01)$ & $10.12^{* * *}$ \\
\hline SES & $-.005(<.01)$ & $-4.90 * * *$ \\
\hline Female & $-.003(<.01)$ & -1.12 \\
\hline Black & $-.020(.01)$ & -1.81 \\
\hline Hispanic/Latino & $.072(.01)$ & $6.63^{* * *}$ \\
\hline Other/Mixed & $.037(.01)$ & $3.25 * *$ \\
\hline \multicolumn{3}{|l|}{ Extracurricular Participation } \\
\hline Sport Only & $.001(<.01)$ & .30 \\
\hline Sport Combo & $-.018(<.01)$ & $-3.91 * * *$ \\
\hline Academic Only & $-.011(.01)$ & -1.62 \\
\hline Performing Arts Only & $.009(.01)$ & 1.42 \\
\hline Other Only & $-.019(.01)$ & $-2.72 * *$ \\
\hline Other Combo & $-.012(.01)$ & $-2.09 *$ \\
\hline \multicolumn{3}{|l|}{ Race*Extracurricular Participation } \\
\hline Black*Sport Only & $-.001(.01)$ & -.12 \\
\hline Black*Sport Combo & $.038(.01)$ & $4.21 * * *$ \\
\hline Black*Academics Only & $.007(.01)$ & .53 \\
\hline Black*Performing Arts Only & $.013(.01)$ & .96 \\
\hline Black*Other Only & $.021(.01)$ & 1.43 \\
\hline Black*Other Combo & $.023(.01)$ & 1.90 \\
\hline Hispanic/Latino*Sport Only & $.002(.01)$ & .22 \\
\hline Hispanic/Latino $*$ Sport Combo & $.027(.01)$ & $2.96 * *$ \\
\hline Hispanic/Latino *Academics Only & $.003(.01)$ & .25 \\
\hline Hispanic/Latino *Performing Arts Only & $.008(.01)$ & .58 \\
\hline
\end{tabular}




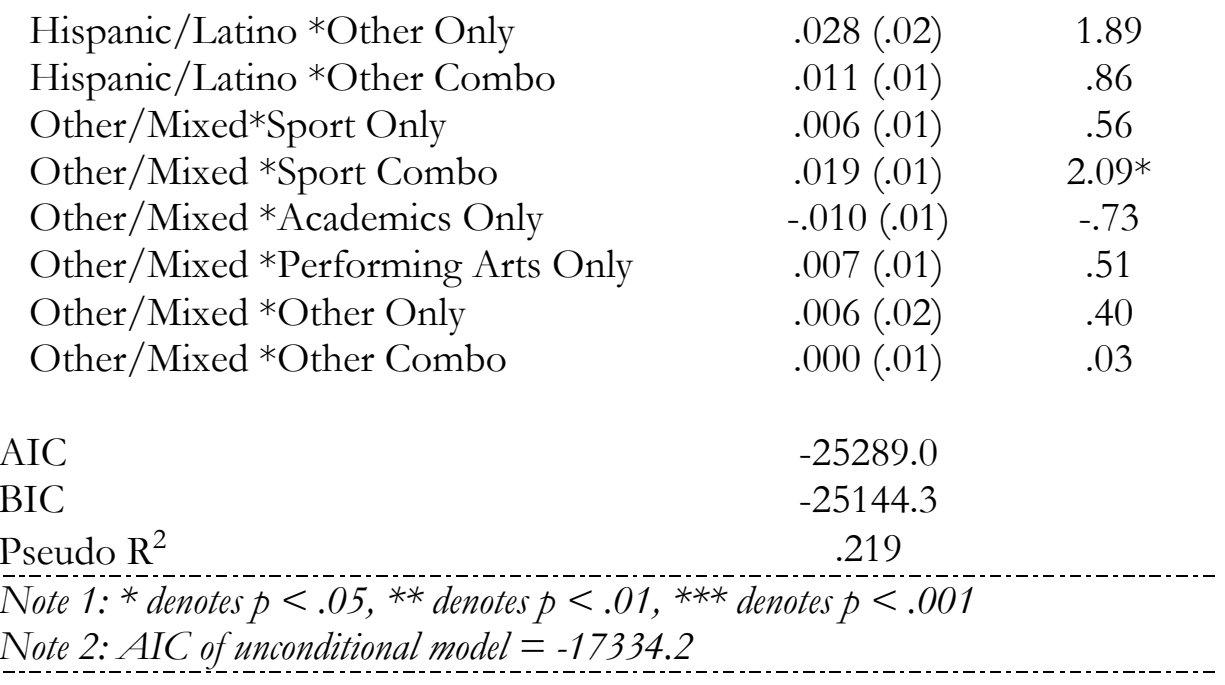

Journal of Amateur Sport Special Issue: Political Economy Jones et al., 2016 


\section{Appendix 2}

\section{Full Mixed-Effects Regression Model 2}

\begin{tabular}{|c|c|c|}
\hline Effect & $B(S E)$ & $t$ \\
\hline Intercept & $.093(.05)$ & $1.99 *$ \\
\hline \multicolumn{3}{|l|}{ School } \\
\hline Busing & $-.044(.02)$ & $-2.24 *$ \\
\hline Urban & $.029(.02)$ & 1.94 \\
\hline Suburban & $.028(.01)$ & $2.18^{*}$ \\
\hline South & $-.018(.01)$ & -1.94 \\
\hline Public & $-.016(.02)$ & -.97 \\
\hline School Size & $<.001(<.01)$ & $2.77 * *$ \\
\hline Relative Density & $.191(.06)$ & $3.40 * * *$ \\
\hline Gender Segregation Index & $.122(.09)$ & 1.40 \\
\hline Grade Segregation Index & $.108(.04)$ & $2.50 *$ \\
\hline Racial Heterogeneity & $.106(.03)$ & $3.61 * * *$ \\
\hline Teacher Heterogeneity & $-.014(.03)$ & -.51 \\
\hline Proportion In-group & $-.212(.01)$ & $-16.86^{* * *}$ \\
\hline \multicolumn{3}{|l|}{ Individual } \\
\hline Bonacich Centrality & $.043(<.01)$ & $10.33^{* * *}$ \\
\hline SES & $-.005(<.01)$ & $-4.86 * * *$ \\
\hline Female & $-.003(<.01)$ & -1.09 \\
\hline Black & $-.010(.01)$ & -1.31 \\
\hline Hispanic/Latino & $.069(.01)$ & $8.29 * * *$ \\
\hline Other/Mixed & $.046(.01)$ & $5.56^{* * *}$ \\
\hline \multicolumn{3}{|l|}{ Extracurricular Participation } \\
\hline Number of Activities & $-.001(<.01)$ & $-2.21 *$ \\
\hline Proportion Sport & $.002(<.01)$ & .61 \\
\hline Size & $.000(<.01)$ & $-2.80 * *$ \\
\hline Heterogeneity & $.122(.01)$ & $10.70^{* * *}$ \\
\hline Racial In-group & $-.038(.01)$ & $-4.20 * * *$ \\
\hline Heterogeneity*Racial In-Group & $-.128(.03)$ & $-4.22 * * *$ \\
\hline AIC & -25464.3 & \\
\hline $\mathrm{BIC}$ & -25362.2 & \\
\hline Pseudo $\mathrm{R}^{2}$ & .220 & \\
\hline $\begin{array}{l}\text { Note 1: }{ }^{*} \text { denotes } p<.05 \text {, ** denotes } \\
\text { Note 2: AIC of unconditional model }=\end{array}$ & 34.2 & \\
\hline
\end{tabular}

